TECHNICAL TRANSACTIONS 7/2018

MECHANICS

DOI: $10.4467 / 2353737$ XCT.18.109.8804 SUBMISSION OF THE FINAL VERSION: 22/06/2018

\author{
Przemysław Nosal (przemek.nosal@gmail.com) \\ Artur Ganczarski \\ Institute of Applied Mechanics, Faculty of Mechanical Engineering, Cracow University \\ of Technology
}

\title{
NumERICAL SIMULATION OF TEMPERATURE DISTRIBUTION DURING \\ THE FIRST STAGE OF THE FRICTION STIR ALLOYING PROCESS
}

\section{SYMULACJA NUMERYCZNA DYSTRYBUCJI TEMPERATURY PODCZAS \\ PIERWSZEJ FAZY PROCESU STOPOWANIA TARCIOWEGO}

Z MIESZANIEM MATERIAEU

\begin{abstract}
This work demonstrates the numerical modelling of thermal dispersion accompanying the first stage of the friction stir alloying process. It is very important to recognise the temperature field in the modified workpiece in order to identify the zones where the physical material properties are changing. The temperature gradient leads to a drop of yield strength of the material and, as a consequence, the occurrence of the possibility of plastic flow around the tool. An attempt has been made to analyse the axisymmetric thermal problem described by a Fourier equation with an internal heat source in which the heat is derived only from work of frictional forces occurring between the workpiece and the tool material. The example under consideration focuses on the production of an Al-TiC composite using FSA technology. Macrostructure images of the composite and the simulation results confirm the correctness of the applied mathematical model, where the obtained temperature field corresponds with specific FSA zones.

Keywords: FSA, temperature field, Al-TiC composite
\end{abstract}

\section{Streszczenie}

Praca dotyczy numerycznego modelowania rozkładu temperatury towarzyszącej pierwszej fazie procesu stopowania tarciowego z mieszaniem materiału. Bardzo ważne jest określenie pola temperatury w modyfikowanym materiale w celu identyfikacji obszarów, gdzie wlaściwości fizyczne materiału ulegają zmianie. Występujący gradient temperatury powoduje obniżenie granicy plastyczności, czego konsekwencją jest umożliwienie plastycznego plynięcia materiału wokół narzędzia mieszającego. Podjęto próbę analizy obrotowo symetrycznego problemu opisanego równaniem typu Fouriera z wewnętrznym źródłem ciepła, gdzie generowane ciepło pochodzi jedynie od pracy sił tarcia występujących pomiędzy materiałem bazowym a materiałem narzędzia. Rozważany problem skupiał się na analizie procesu wytwarzania kompozytu Al-TiC za pomocą technologii FSA. Zdjęcia makrostruktury kompozytu oraz wyniki symulacji numerycznej potwierdzają poprawność zastosowanego modelu matematycznego, a otrzymane pole temperatury nawiązuje do stref wlaściwych dla procesu FSA.

Słowa kluczowe: FSA, rozkład temperatury, kompozyt Al-TiC 
Nomenclature

$\begin{array}{cccc}c_{\mathrm{v}} & \text { specific heat } & \alpha & \text { stability coefficient } \\ d & \text { diameter of the pin } & \beta & \text { convection coefficient } \\ \mathrm{D} & \text { diameter of the shoulder } & \lambda & \text { thermal conductivity } \\ h & \text { height of the pin } & \rho & \text { mass density } \\ r, \varphi, z & \text { cylindrical coordinates } & \theta, \theta_{\infty} & \text { temperature, ambient temperature } \\ r, R & \text { radii of the pin and the shoulder } & \tau_{\text {cont }} & \text { shear yield strength } \\ Q & \text { heat } & \omega & \text { angular velocity } \\ t & \text { time } & \Delta \mathrm{r}, \Delta \mathrm{t} & \text { spatial increment and time increment } \\ w_{s l} & \text { thickness of the shear layer } & & \end{array}$

\section{Introduction}

Recently, engineers have been increasingly using innovative materials in modern constructions. The properties of these materials are much better than properties of traditional materials, such as steel. Examples of this type of material are aluminium matrix composites (AMCs) which are reinforced by particles such as $\mathrm{TiC}, \mathrm{SiC}, \mathrm{B}_{4} \mathrm{C}$ or $\mathrm{Al}_{2} \mathrm{O}_{3}$ [1-4]. These composites have many applications, e.g. in the automotive industry, the aerospace industry and in the military. They are characterised by their high stiffness and strength to weight ratio. They also have high heat resistance and tribological properties. Additionally, in the case of cyclic loads, their fatigue properties are high. Very interesting variations of these composites are the functionally graded materials which allow their use in extreme environments [5-7]. The reason why they are not used more widely is the high production costs of currently used technologies. However, some researchers are trying to make these types of composites using friction stir processing technology (FSP) and the results of these attempts appear to be promising [1-3] (Fig. 1). They observed that the reinforcement particle distribution in the aluminium matrix changes gradually through its thickness and there are no particle-poor or particle-rich zones in the microstructure [1]. Scientists now wish to optimise this process and check if the technology parameters influence the material properties of the modified layer with regard to, for example, yield strength, total elongation and micro-hardness. Due to the fact that it is a relatively new method of obtaining FGCM (functionally graded composite materials), there is no adequate mathematical model which describes its behaviour under external loads. Salehi et al. [1] tried to use a simple equation from continuum mechanics to estimate the composite yield strength; however, this model fails to consider gradation of this property. Generally, regarding composites made using FSP technology, there is a lack of this kind of material description. Most of the publications are focussed on modelling behaviour of friction stir welded joints using some modifications of the Johnson-Cook material model $[8,9]$, the Voce model $[10,11]$ or a modified Gurson model $[12,13]$; however, neither of them have implemented dependence from the process parameters. During the FSP process, 
the tool affects the workpiece and the parameters (rotation speed and feed rate) determine the amount of generated heat energy and the manner of material flow [14]. The material behaviour of individual zones in FSP composites is closely related to the microstructures of the zones which are determined by influence of the tool [15-17]. Friction stir processing is a variation of a friction stir welding technology which was developed at the end of the twentieth century by Wayne Thomas in the Welding Institute (UK) [18]. As was shown, FSP allows the application of the benefits of FSW in different ways e.g. the layer of the porous materials can be modified where the microstructure of it is grained [19]. Sometimes when the process of manufacturing composites using FSP technology is described, some researches use the term 'friction stir alloying' (FSA). As is the case with FSW, during FSP/FSA, heat energy is generated by two phenomena. Firstly, by friction between the material of the tool and the base material, and secondly, by energy dissipation of plastic strain work. Increase of temperature causes softening of the workpiece which allows mixing of the materials in the case of the manufacturing composite [20].

In the present study, 2D heat distribution during the first stage of the FSA process in the $\mathrm{Al}-\mathrm{TiC}$ composite was investigated using the developed model which uses a nonstationary Fourier equation. In this analysis, heat is generated only by the first mechanism which corresponds with the friction between the tool and the base material. To confirm the simulation results, the received temperature field map which accompanies the first stage of the FSA process was compared with a macrostructural image of the composite made experimentally with the assumed technological parameters and the same configuration of added $\mathrm{TiC}$ powder. The results depict that the FSA parameters influence the amount of generated heat energy and its dispersion in the workpiece.
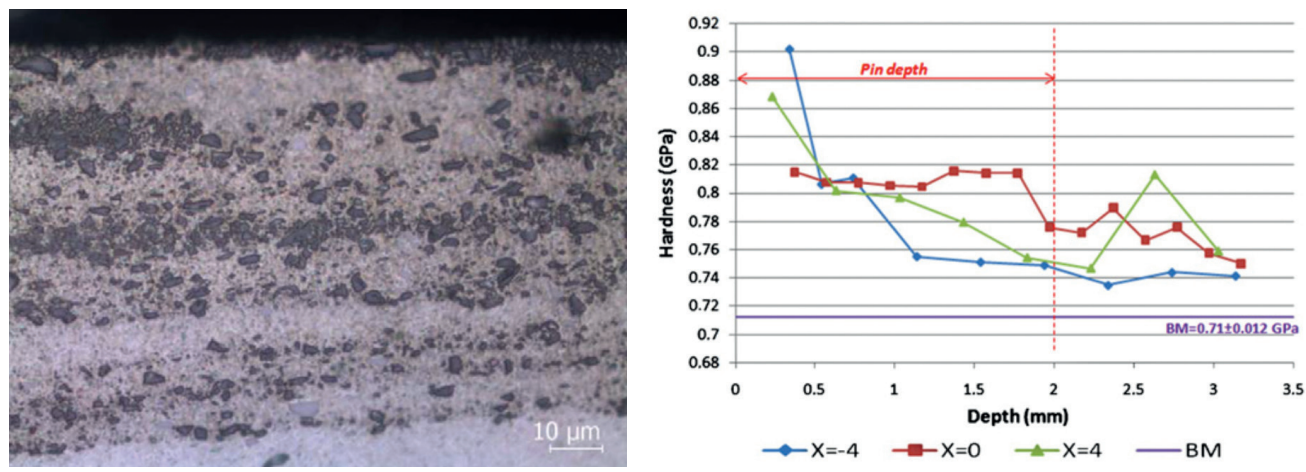

Fig. 1. Macrostructural image of the $\mathrm{Al}-\mathrm{SiC}$ composite from the advancing side and the related hardness profiles diagram [2]

\section{Model}

Each of the welding techniques have an effect on the local mechanical properties of the formed joint [21] which closely correlates with the high temperature which occurs during the welding processes and is needed to increase the enthalpy joining materials in order to conduct 
the adhesion phenomenon process. In the case of FSA technology, heat is generated by the tool and it is self stabilising [12]. The maximum temperature does not reach the melting point of the joined or mixed materials [14]. The first stage of the FSA process consists of penetration initiation of the workpiece and short period of time for first dwelling. This is a very important stage because during this time, the temperature significantly increases, which allows material to flow around the probe. These two phenomena are complex and coupled and affect the material microstructure which, as a consequence, affects the material behaviour under external loads $[8,15-17,22]$. The ensuing plastic deformation and its directions are related to the tool geometry and the motion of this tool; therefore, the asymmetry in stirred zone is an important subject of observation (Fig. 2).

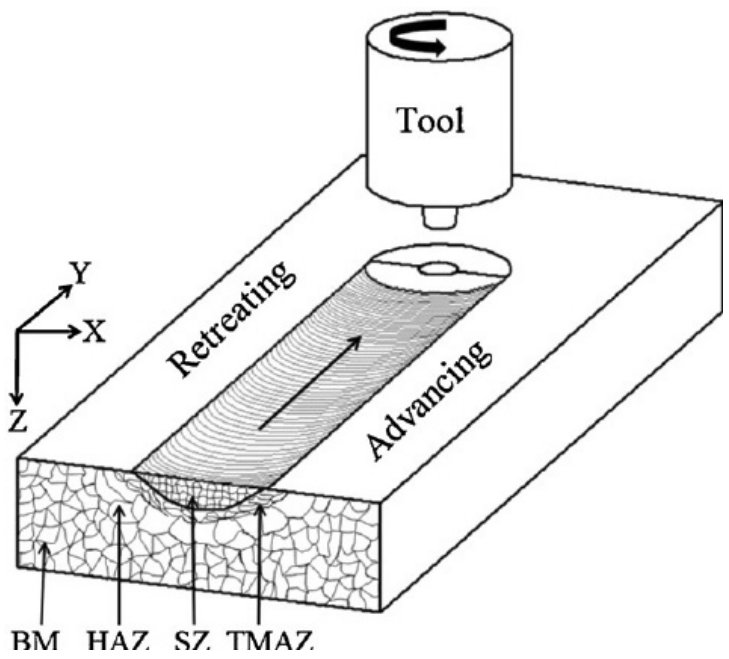

Fig. 2. Scheme of the FSP process [23]

The region modified by FSP has similar microstructural zones to the FSW method. We can distinguish between the stir zone - SZ, the heat affected zone-HAZ, the thermo-mechanical affected zone - TMAZ and the base material - BM. Micallefet et al. [24] and Shi et al. [25] used CFD simulations to predict heat generation and material flow during the FSW process. Interesting models were developed by Kang et al. [26], who propose models which include only the plastic deformation process as a mechanism of heat energy generation. This article focuses only on the frictional mechanism of heat generation, and the plastic deformation of the material is not currently considered. At the beginning of the FSP or FSW process study, thermal modelling is needed because this step allows the elimination of those parameters which can lead to the welding nonconformities like voids. Thus, the quality of the mixed zone is dictated by the thermal history of the process and the plastic deformation.

The tool generally used has two functions: it transforms mechanical energy into heat energy and induces the material flow inside the stirring zone. The amount of heat energy generated is determined by the influence of the individual active surfaces of the tool: the pin tip surface ( $p t)$, the pin side surface ( $p s)$ and the shoulder tip surface (st) (Fig. 3a). 


$$
Q_{T}=Q_{p s}+Q_{p t}+Q_{s t}
$$

Each of these surfaces generates a certain amount of heat energy; however, the biggest contribution to this value is the shoulder, which constitutes around $90 \%$ of this energy [20]. Moataz [27] presents analytical models for the calculation of heat inputs. A Chao model was used in this study.

a)

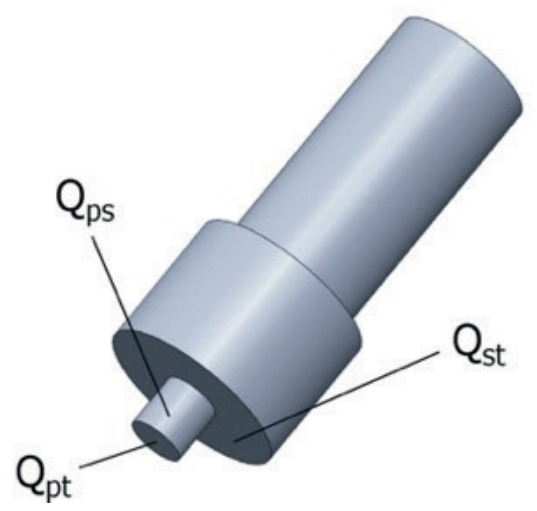

b)

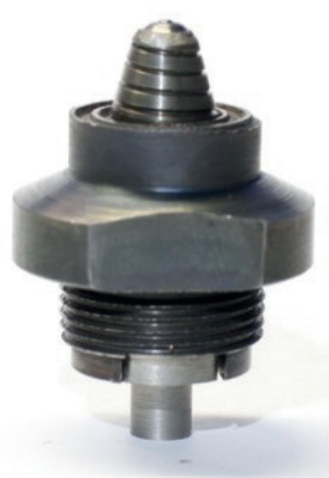

Fig. 3. FSW tool: a) individual tool areas which determine the amount of generated heat energy;

b) real welding tool with conical pin and cut spirals on the pin and the shoulder

$$
\left.\begin{array}{l}
Q_{p s}=\int_{0}^{2 \pi} \int_{0}^{h} \omega \tau_{\text {cont }} r^{2} d \varphi d z \\
Q_{p t}=\int_{0}^{\frac{d}{2}} \int_{0}^{2 \pi} \omega \tau_{\text {cont }} r^{2} d \varphi d r \\
Q_{s t}=\int_{0}^{2 \pi} \int_{\frac{d}{2}}^{\frac{D}{2}} \omega \tau_{\text {cont }} r^{2} d \varphi d r
\end{array}\right\}
$$

Individual values of energy contributors from equation (1) can be calculated by integrals (2) [28]. It is assumed that all variables, for example, yield strength $\left(\sigma_{y}\right)$ and thermal conductivity, are independent from temperature and time. This assumption is not in accordance with reality; however, it is sufficient to observe the trends which combine with the temperature flow across the workpiece. The opposite assumption was made by Mijajlovic and Milic [28] who considered the influence of many parameters on generated heat energy, where these parameters are mutually dependent.

In equation (2), $\omega-$ is radial frequency, $\tau_{\text {cont }}$ - is contact shear stress of the interface located between the shear layer of the workpiece and the tool, and is expressed by, $\tau_{\text {cont }}=\frac{\sigma_{y}}{\sqrt{3}}, r$ - is the radius of analyzed part of the tool. Because the heat energy which is generated by probe is relatively small, it can be neglected in the next calculations and the total generated heat energy can be described as: 


$$
Q_{T}=\frac{2}{3} \omega R_{\text {shoulder }} \mu F_{z}
$$

In reality, heat is generated by those surfaces which are in contact with the base material; thus, the heat source is heterogeneous because the active surfaces affect the workpiece in a nonlinear manner. Additionally, the friction phenomena which occur during this process are complex and difficult to model. Some of the material can stick to the tool and some of it can slip; the ratio between these two occurrences is difficult to estimate. For simplification, the spatial dispersion of the volume intensity heat source was assumed to be:

$$
\dot{q}_{v}=\frac{3 Q_{T} r}{2 \pi R_{\text {shoulder }}^{3} w_{s l}}
$$

where the heat affects a very thin material layer expressed by variable, which describes the width of the shear layer.

This definite heat source was used as the excitation in a non-stationary Fourier equation, which in case of modelling the first stage of the FSA process, is rotational symmetry.

$$
\lambda\left(\frac{\partial^{2} \theta}{\partial r^{2}}+\frac{1}{r} \frac{\partial \theta}{\partial r}+\frac{\partial^{2} \theta}{\partial z^{2}}\right)+\dot{q}_{v}=\rho c_{v} \frac{\partial \theta}{\partial t}
$$

\section{Experimental and numerical examples}

In the present study, 6082-T6 aluminium alloy sheets $(2 \mathrm{~mm} \times 50 \mathrm{~mm} \times 110 \mathrm{~mm})$ were used as the base material. The configuration used has the best quality of macro- and microstructure of the obtained modified layer from a set of possible FSA strategies. The aluminium sheets were separated by titanium carbide powder (with a purity of $98 \%$ and an average diameter of $44 \mu \mathrm{m}$ ) which served as a reinforcement; the thickness of this layer was $0.1 \mathrm{~mm}$. The materials were mixed together in order to form a composite (Fig. 4).

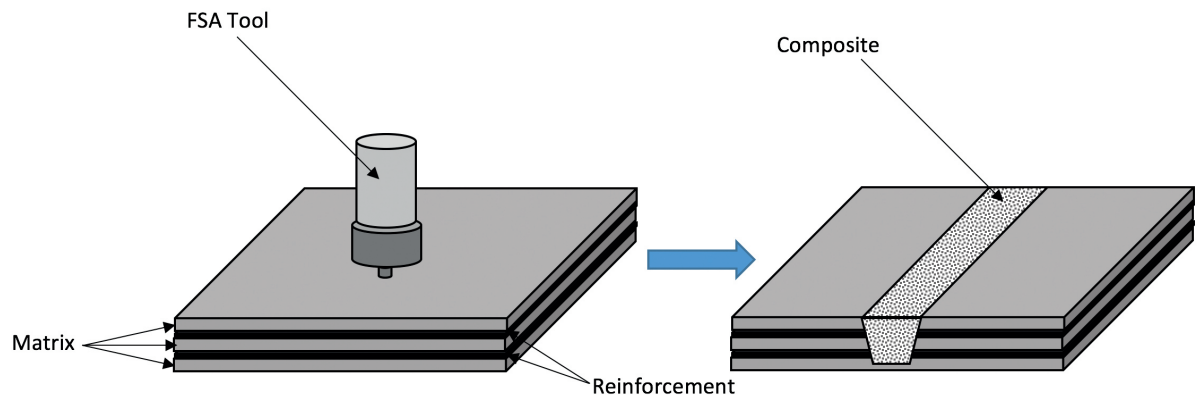

Fig. 4. Strategy of powder implementation in the FSA process

The new material was made using FSA technology on a standard milling machine (Fig. 5). The rotation speed $\left(V_{n}\right)$ was $560 \mathrm{~min}^{-1}$, the penetration speed $\left(V_{p}\right)$ was $12 \mathrm{~mm} / \mathrm{min}$ and the travelling speed $\left(V_{z}\right)$ was $40 \mathrm{~mm} / \mathrm{min}$. The time for the first dwelling was set at 3 seconds. 
The tilt angle of the rotation tool was set at $0^{\circ}$. The tool has a conically shaped threaded probe with a root diameter of $8 \mathrm{~mm}$ and a length of $5 \mathrm{~mm}$. The shoulder has a diameter of $20 \mathrm{~mm}$ and milled spiral on its tip (Fig. 3b). The nominal thermo-physical properties of the materials used in the simulation are listed in Table 1.

Table 1. Physical properties of the tool material, the $\mathrm{TiC}$ powder and the aluminium plate

\begin{tabular}{|c|c|c|c|}
\hline Material & $\rho[\mathrm{g} / \mathrm{cm} 2]$ & $\lambda[\mathrm{W} / \mathrm{cm} \cdot \mathrm{K}]$ & $c_{\mathrm{v}}[\mathrm{J} / \mathrm{g} \cdot \mathrm{K}]$ \\
\hline Tool - Tungsten alloy & 19.25 & 175 & 0.135 \\
\hline Added phase - TiC powder & 4.92 & 110 & 0.520 \\
\hline Matrix - Al 6082-T6 & 2.71 & 172 & 0.894 \\
\hline
\end{tabular}

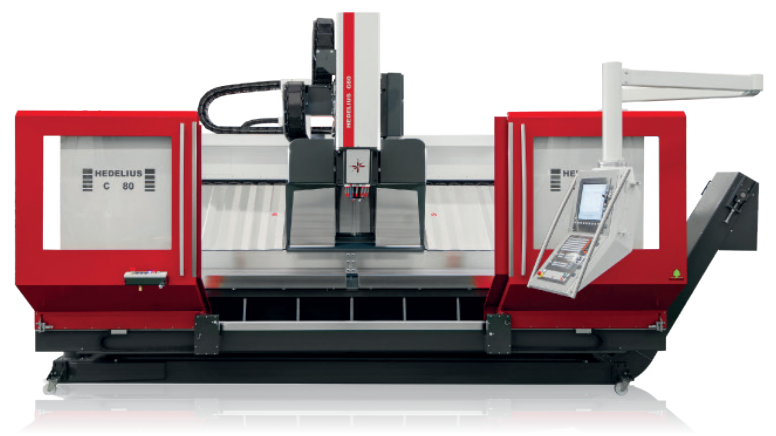

Fig. 5. CNC milling machine used in the FSA process

The boundary conditions (Fig. 6) of the numerical simulation were modelled using equations corresponding with the boundary conditions of the experimental test; however, the analysis refers only to the first stage of the FSA process. The author developed his own script in the MATLAB environment which uses the finite difference method based on a fully implicit scheme [29].

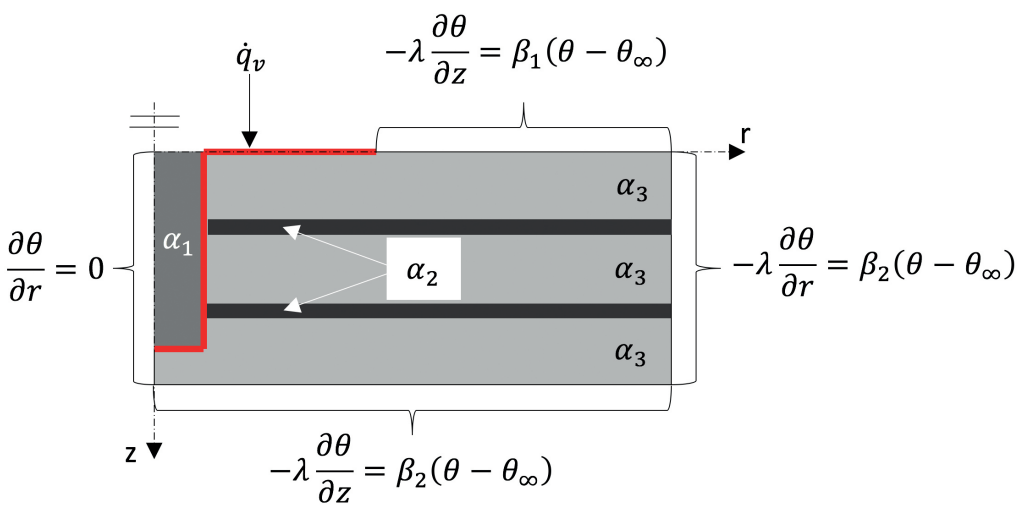

Fig. 6. Geometrical scheme and the boundary conditions of the analysed problem (von Neumann's stability coefficients for: tool $-\alpha_{1}$, added phase $-\alpha_{2}$ and matrix $-\alpha_{3}$ ) 
Used method requires the fulfilment of von Neumann's stability equation $\alpha=\frac{\lambda}{\rho c_{V}} \frac{\Delta t}{(\Delta r)^{2}}$ Additionally, the value of the stability coefficient is different for each material used in simulation. The rectangle domain was discretised by an element with a nominal length of $0.1 \mathrm{~mm}$. The mesh size was $63 \times 250$ and each point of it has applied the differential equation (6).

$$
\begin{aligned}
& \alpha\left(1-\frac{\Delta r}{2 r_{i}}\right) \theta_{i-1, j}^{\text {new }}+\alpha \theta_{i, j-1}^{\text {new }}-(1+4 \alpha) \theta_{i, j}^{\text {new }}+ \\
& +\alpha \theta_{i, j+1}^{\text {new }}+\alpha\left(1+\frac{\Delta r}{2 r_{i}}\right) \theta_{i+1, j}^{\text {new }}=-\theta_{i, j}^{\text {old }}-\frac{\dot{q}_{v} \Delta t}{\rho c_{V}}
\end{aligned}
$$

This equation also contains the unknowns of the points which are located outside the domain; in this case, the determination of their values requires usage of the appropriate boundary condition scheme which consists of combinations of unknowns at internal points (see Fig. 6). Each iteration generates a set of linear algebraic equations which can be written as

$$
\boldsymbol{A x}=\boldsymbol{b}
$$

Structure of the matrix is typical of sparse systems which can be solved by using difference methods e.g. Gauss elimination or the conjugate gradient method with row-indexed compact storage [29]. These methods are very efficient because the computing elements which contain zero values are not used; therefore, the time of the whole simulation is shorter.

The macrostructural image of the obtained $\mathrm{Al}-\mathrm{TiC}$ composite produced in the experimental test confirms the good quality of the modified layer (Fig. 7). The mixed zone of the two phases which is located on the upper side of the sample contains circle oxide lines which are peculiar to the aluminium joints. They additionally include the $\mathrm{TiC}$ particles. The composite layer was obtained by one pass of the FSA tool.

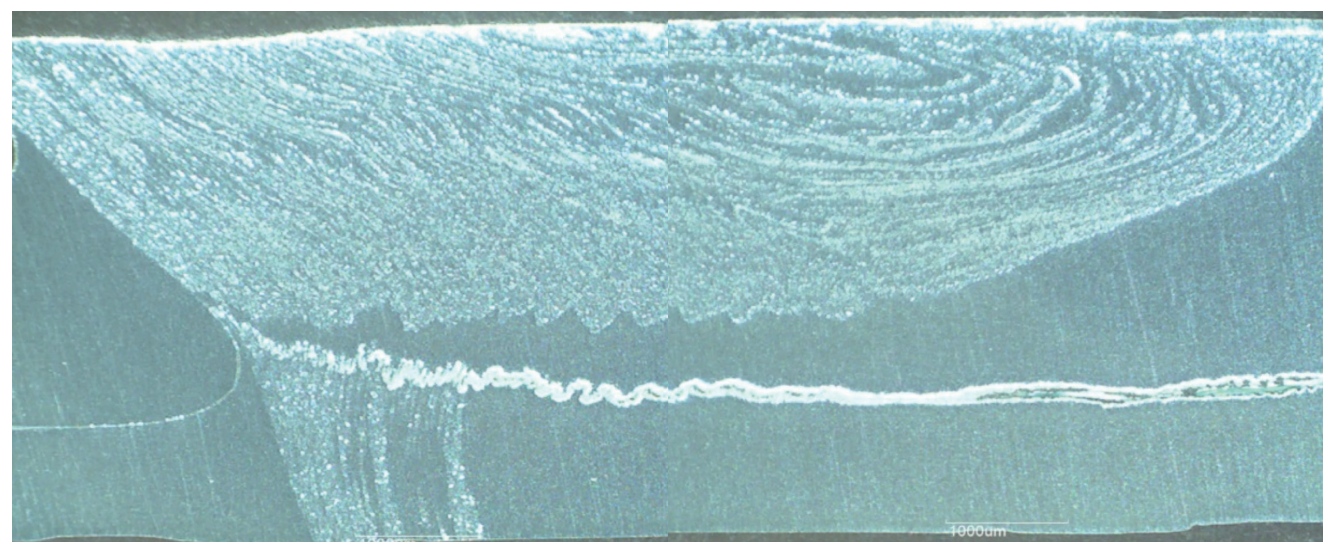

Fig. 7. Macrostructure image of the sample Al-TiC composite produced with one pass of the welding tool 
The results from the simulation confirm the qualitative temperature distribution field in the workpiece after the end of the first stage of the FSA process (Fig. 8). The maximum temperature of the plunge stage is around $390^{\circ} \mathrm{C}$ and is located where both parts of the tool (pin and shoulder) are joined. The skew isotherms are typical for this kind of technology and change during the tool penetration process. The heat influence of the added shoulder allows the curvature to stabilise itself. The zones which are set down by these isotherms are related to the respective zones in the FSW/FSA join structure. A high drop in the temperature field is observed in place which is proper to the heat affected zone (HAZ); whereas, at the point where the thermomechanically affected zone is typically located, the temperature is almost homogeneous.

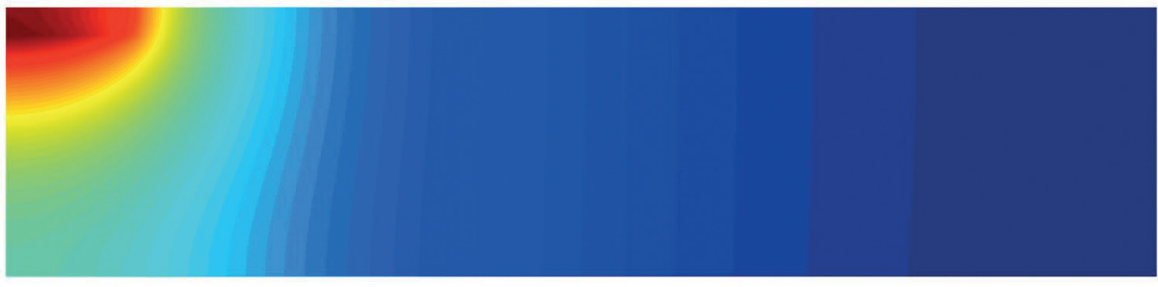

a)
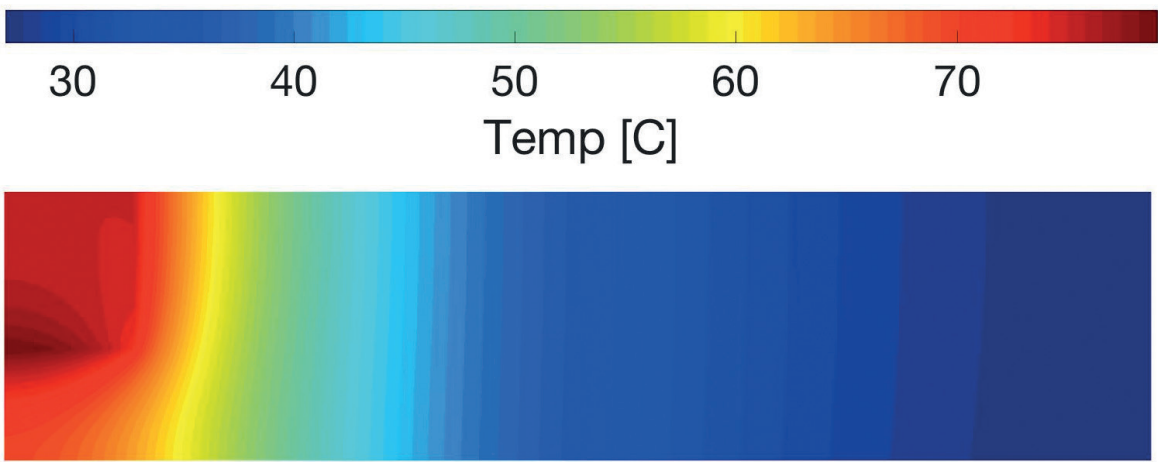

b)
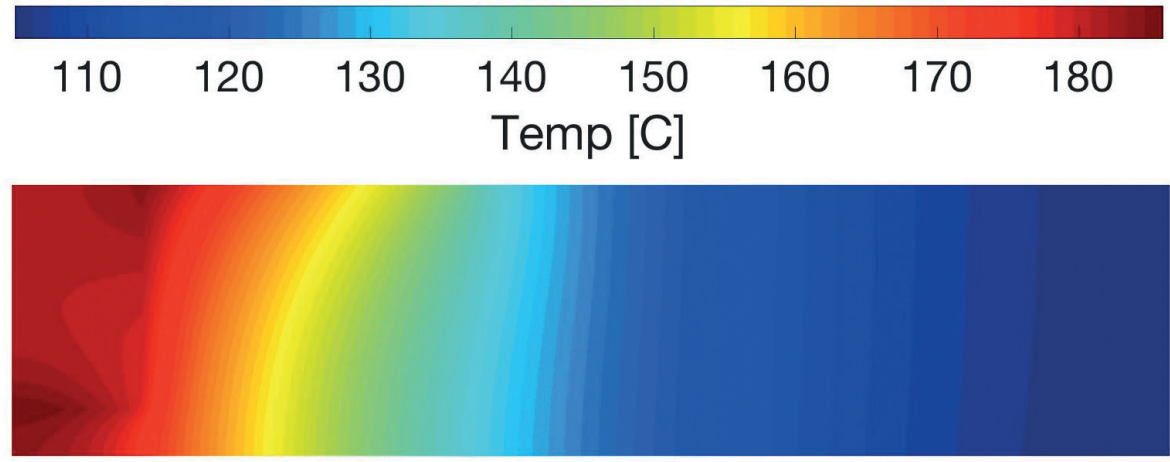

c)

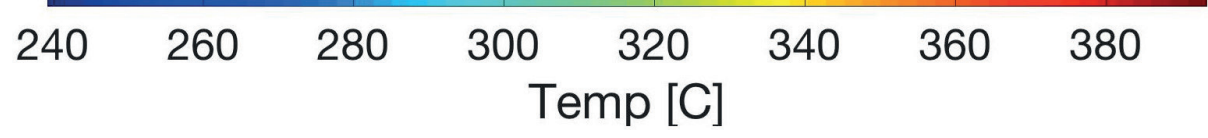

Fig. 8. Temperature fields in different periods of the tool penetration in the base material: a) time $4 \mathrm{~s}$ - depth of the pin $0.8 \mathrm{~mm}$; b) time $18 \mathrm{~s}$ - depth $3.6 \mathrm{~mm}$; ) time $28 \mathrm{~s}$ - depth $5 \mathrm{~mm}$ 


\section{Conclusions}

The temperature field map was obtained as a result of solving the boundary problem of producing an $\mathrm{Al}-\mathrm{TiC}$ composite by using FSA technology. It was observed that after adding the shoulder heat influence, the rate of temperature change increases and this confirms that this part of the tool has the largest effect on the material. The skew isotherms are specific for this technology and are dictated by the combined heat influence from the probe and the shoulder. They correlate with the respective zones in the FSA composite e.g. with the HAZ area. The maximum temperature occurs at the end of dwelling time (around 28 seconds) when the tool fully penetrates the material and the value of it is about 390 degrees of Celsius. This is lower than the melting point of this aluminium alloy which corresponds with this technology property. The highest temperature is located in the place where both parts of the tool are joined.

Future research should also focus upon the development of a new mathematical model which will include the impact of plastic deformation on the generated heat energy and the variable dependence from the temperature. Also it assumes the development of the 3D simulation of two-phase material flow in the stirring zone during all stages in order to estimate the $\mathrm{TiC}$ particle distribution inside the composite. New experiments will be performed to obtain data concerning temperature profiles, downward force, traverse force and torque.

\section{References}

[1] Salehi M., Farnoush H. and Mohandesi J.A., Fabrication and characterization of functionally graded $\mathrm{Al}-\mathrm{SiC}$ nanocomposite by using a novel multistep friction stir processing, Jour. of Mat. and Des., 63(C), 2014, 419-426.

[2] Gandra J., Miranda R., Vilaça P., Velhinho A. and Teixeira J.P., Functionally graded materials produced by friction stir processing, Journal of Materials Processing Tech., 211(11), 2011, 1659-1668.

[3] Miranda R.M., Santos T.G., Gandra J., Lopes N., Silva R.J.C., Reinforcement strategies for producing functionally graded materials by friction stir processing in aluminium alloys, Journal of Materials Processing Tech., 213(9), 2013, 1609-1615.

[4] Veličković S., Garić S., Stojanović B., Vencl A., Tribological properties of aluminium matrix nanocomposites, Applied Engineering Letters, 1(3), 2016, 72-79.

[5] Bohidar S.K., Sharma R., Mishra P.R., Functionally Graded Materials: A Critical Review, International Journal of Scientific Footprints, 2(4), 2014, 18-29.

[6] Kohli G.S., Singh T., Review of functionally graded materials, Journal of Production Engineering, 18(2), 2015, 1-4.

[7] Udupa G., Rao S.S., Gangadharan K.V., Functionally Graded Composite Materials: An Overview, Procedia Materials Science, 5, 2014, 1291-1299.

[8] Grujicic M., Pandurangan B., Yen C.F., Cheeseman B.A., Modifications in the AA5083 Johnson-Cook Material Model for Use in Friction Stir Welding Computational Analyses, Journal of Materials Engineering and Performance, 21(11), 2011, 2207-2217. 
[9] Sanjeev N.K., Malik V., Hebbar H.S., Verification of Johnson-Cook material model constants of AA2024-T3 for use in finite element simulation of friction stir welding and its utilization in severe plastic deformation process modelling, IJRET, 3(6), 2014, 98-102.

[10] Simar A., Bréchet Y., de Meester B., Denquin A., Pardoen T., Microstructure, local and global mechanical properties of friction stir welds in aluminium alloy 6005A-T6, Materials Science \& Engineering, 486(1), 2008, 85-95.

[11] Zhang L., Min J., Wang B., Lin J., Li F., Liu J., Constitutive model of friction stir weld with consideration of its inhomogeneous mechanical properties, Chin. J. Mech. Eng., 29(2), 2016, 357-364.

[12] Nielsen K.L., Pardoen T., Tvergaard V., de Meester B., Simar A., Modelling of plastic flow localisation and damage development in friction stir welded 6005A aluminium alloy using physics based strain hardening law, International Journal of Solids and Structures, 47(18), 2010, 2359-2370.

[13] Borino G., Fratini L., Parrinello F., Mode I failure modeling of friction stir welding joints, Int. J. Adv. Manuf. Technol., 41(5), 2008, 498-503.

[14] Mishra R.S., Mahoney M.W., Friction Stir Welding and Processing, ASM International, Ohio 2008

[15] Lockwood W.D., Tomaz B., Reynolds A.P., Mechanical response of friction stir welded AA2024: experiment and modeling, Materials Science and Engineering, A323, 2002, 348-353.

[16] Zhang Z.H., Li W.Y., Li J.L., Chao Y.J., Effective predictions of ultimate tensile strength, peak temperature and grain size of friction stir welded AA2024 alloy joints, Int. J. Adv. Manuf. Technol., 73(9), 2014, 1213-1218.

[17] Cho H.H., Kim D.W., Hong S.T., Jeong Y.H., Lee K., Cho Y.G., Kang S.H., Han H.N., Three-Dimensional Numerical Model Considering Phase Transformation in Friction Stir Welding of Steel, Metal. and Mat. Trans., 46(12), 2015, 6040-6051.

[18] Thomas W.M., Nicholas E.D., Needham J.C., Murch M.G., Temple-Smith P., Dawes C.J., Improvements relating to friction stir welding, Patent no: 5460317, 1999.

[19] Węglowski M.S., Friction stir processing - State of the art, Archives of Civil and Mechanical Engineering, 18(1), 2017, 114-129.

[20] Lohwasser D., Chen Z., Friction Stir Welding. From basics to applications, CRC, Cambridge 2010

[21] Lockwood W.D., Reynolds A.P., Simulation of the global response of a friction stir weld using local constitutive behavior, Materials Science and Engineering, A339, 2003, 35-42.

[22] He W., Luan B., Xin R., Xu J., Liu Q. A multi-scale model for description of strain localization in friction stir welded magnesium alloy, Computational Materials Science, 104(C), 2015, 162-171.

[23] Yadav D., Bauri R., Effect of friction stir processing on microstructure and mechanical properties of aluminium, Materials Science and Engineering, 539, 2012, 85-92.

[24] Micallef D., Camilleri D., Toumpis A., Galloway A., Arbaoui L., Local Heat Generation and Material Flow in Friction Stir Welding of Mild Steel Assemblies, Journal of Materials: Design and Application, 230(2), 2016, 586-602. 
[25] Shi L., Wu C.S. Liu H.J., Modeling the Material Flow and Heat Transfer in Reverse DualRotation Friction Stir Welding, Journal of Materials Engineering and Performance, 23(8), 2014, 2918-2929.

[26] Kang S.W., Jang B.S., Kim J.W., A study on heat-flow analysis of friction stir welding on a rotation affected zone, J. Mech. Sci. Technol., 28(9), 2014, 3873-3883.

[27] Moataz A., Friction Stir Welding of aluminium alloys, Lambert, Birmingham, 2007.

[28] Mijajlovic M., Milcic D., Analytical Model for Estimating the Amount of Heat Generated During Friction Stir Welding: Application on Plates Made of Aluminium Alloy 2024 T351, InTech, 11, 2012.

[29] Press W.H., Teukolsky S.A., Vetterling W.T., Flannery B.P., Numerical recipes in fortran, Cambridge University Press, Cambridge 1993. 